\title{
Perbedaan Kemampuan Representasi Matematis Siswa Yang Diajar Dengan Teknik Scaffolding Dan Yang Diajar Dengan Pembelajaran Konvensional Di Kelas X SMK Negeri 05 Bombana
}

\author{
(The Differences Of Mathematical Representation Ability Students Treated With \\ Scaffolding Techniques And Teached With Conventional Learning In Class X \\ SMK Negeri 05 Bombana)
}

\author{
Sima Yuningsih ${ }^{1}$, Kadir $^{2}$, La Ndia $^{3}$, Saleh $^{3}$ \\ ${ }^{1}$ Alumnus Jurusan Pendidikan Matematika FKIP Universitas Halu Oleo; Co-author: \\ simayuningsih01@gmail.com \\ ${ }^{2}$ Dosen Pendidikan Matematika FKIP dan PPS Universitas Halu Oleo \\ ${ }^{3}$ Dosen Pendidikan Matematika FKIP Universitas Halu Oleo
}

\begin{abstract}
Abstrak: Penelitian ini dilatarbelakangi oleh rendahnya kemampuan representasi matematis siswa. Penelitian ini merupakan penelitian eksperimen semu dengan rancangan posttest only control group design. Populasi dalam penelitian ini adalah seluruh siswa kelas X SMK Negeri 05 Bombana yang terdiri dari tiga kelas dengan jumlah siswa 73 siswa. Penentuan sampel dilakukan secara purposive sampling diperoleh kelas X Jurusan ATPH sebagai kelas eksperimen dan kelas X Jurusan TITL sebagai kelas kontrol. Berdasarkan hasil analisis data diperoleh kesimpulan: (1) Kemampuan representasi matematis siswa kelas X Jurusan ATPH yang yang diajar dengan teknik scaffolding pada materi trigonometri memiliki nilai rata-rata kemampuan representasi gambar 67,56, kemampuan representasi simbol 78,92, dan verbal 74,80; (2) Kemampuan representasi matematis siswa kelas X Jurusan TITL yang diajar dengan pembelajaran konvensional pada materi trigonometri memiliki nilai rata-rata kemampuan representasi gambar 53,96, simbol 66, dan verbal 62,92: dan (3) Kemampuan representasi matematis siswa yang diajar dengan teknik scaffolding lebih tinggi daripada kemampuan representasi matematis siswa yang diajar dengan pembelajaran konvensional.
\end{abstract}

Kata kunci: Teknik Scaffolding, Kemampuan Representasi Matematis, Model Pembelajaran Konvensional.

\begin{abstract}
This research is motivated by the low ability of students' mathematical representation. This research is a quasi experiment research with posttest only control group design. The population in this study is all students of class X SMK Negeri 05 Bombana consisting of three classes with the number of students 73 students. Determination of sample is done by purposive sampling obtained class X Department of ATPH as experiment class and class X Department of TITL as control class. Based on the result of data analysis, it can be concluded: (1) The ability of the mathematical representation of the class X students of ATPH who are taught by scaffolding technique on trigonometric material has the mean value of image representation capability 67,56 , symbol representation ability 78,92, and verbal 74, 80; (2) The ability of mathematical representation of $\mathrm{X}$ grade students TITL department which is taught by conventional learning on trigonometric material has mean value of image representation ability 53,96, symbol 66, and verbal 62,92: and (3) ability of student's mathematical representation which is taught with scaffolding technique is higher than the ability of mathematical representation of students who are taught with conventional learning.
\end{abstract}

Keywords: Scaffolding Techniques, The Ability Of Mathematical Representation, Learning Model Conventional.

\section{PENDAHULUAN}

Matematika adalah salah satu mata pelajaran yang diajarkan di sekolah. Matematika memiliki karakteristik yang

berbeda dengan mata pelajaran yang lain. Pada dasarnya objek matematika adalah abstrak (Sukarman, 2002: 9) sehingga 
siswa terkadang mengalami permasalahan dalam memahami suatu materi pada pembelajaran matematika.

Adapun tujuan mata pelajaran matematika untuk semua jenjang pendidikan dasar dan menengah adalah agar siswa mampu: (1) Memahami konsep matematika, menjelaskan keterkaitan antarkonsep, dan mengaplikasikan konsep atau algoritma secara luwes, akurat, efisien, dan tepat dalam pemecahan masalah, (2) Menggunakan penalaran pada pola dan sifat, melakukan manipulasi matematika dalam membuat generalisasi, menyusun bukti, atau menjelaskan gagasan dan pernyataan matematika; (3) Memecahkan masalah yang meliputi kemampuan memahami masalah, merancang model matematika, menyelesaikan model, dan menafsirkan solusi yang diperoleh; (4) Mengkomunikasikan gagasan dengan simbol, tabel, diagram, atau media lain untuk memperjelas keadaan atau masalah; dan (5)Memiliki sikap menghargai kegunaan matematika dalam kehidupan, yaitu rasa ingin tahu, perhatian, dan minat dalam mempelajari matematika, serta sikap ulet dan percaya diri dalam pemecahan masalah (Effendi, $2013: 1$ ).

Dalam proses pembelajaran matematika, diperlukan kemampuan untuk mengungkapkan dan merepresentasikan gagasan/ide matematis merupakan suatu hal yang harus dilakukan oleh setiap orang yang belajar matematika. Di samping itu, matematika berfungsi untuk mengembangkan kemampuan berkomunikasi dengan menggunakan bilangan dan simbol-simbol serta ketajaman penalaran yang dapat membantu memperjelas dan menyelesaikan permasalahan dalam kehidupan sehari-hari.

Kemampuan representasi matematis merupakan kemampuan menyatakan idea tau gagasan matematis dalam bentuk gambar, grafik, tabel, diagram, persamaan atau ekspresi matematika, simbol-simbol, tulisan atau kata-kata tertulis. Kemampuan representasi matematis membantu siswa dalam membangun konsep, memahami konsep dan menyatakan ide-ide matematis, serta memudahkan untuk mengembangkan kemampuan yang dimilikinya. Salah satu pencapaian dalam proses pembelajaran matematika hendaknya menjamin siswa agar bisa menyajikan konsep-konsep yang dipelajarinya dalam berbagai macam model matematika, membantu mengembangkan pengetahuan siswa secara lebih mendalam, dengan cara guru memfasilitasi mereka melalui pemberian kesempatan yang lebih luas untuk merepresentasikan gagasan-gagasan matematis.

Teknik scaffolding merupakan ide penting dari Vygotsky, di mana pemberian bantuan oleh pendidik kepada siswa pada proses pembelajaran disaat yang tepat dan menghentikan bantuan tersebut dengan memberikan kesempatan kepada siswa untuk mengambil alih tanggung jawab setelah siswa mampu untuk menyelesaikan permasalahan sehingga dapat mencapai tujuannya. Scaffolding yang dilakukan oleh pendidik dapat memberikan instruksi akademis kepada siswa yang membutuhkan untuk mengembangkan konseptual pada anak dan dapat membantu proses pembelajaran Walqui (Nofiansyah, 2015: 949) Pendidik hanya membantu proses pemberian bantuan dengan berbagai teknik sehingga hal yang demikian dapat mendorong keterlibatan aktif siswa.

Ide scaffolding pertama kali dikemukakan oleh Lev Vygotsky. Hartman (2002) menyatakan bahwa teori Vygotsky memperkenalkan mengenai konstruktivis sosial yang terdiri dua hal, yaitu belajar interaksi sosial dan zone of proximal development (ZDP). Teknik scaffolding dikatakan kontriktivis karena siswa dapat membangun sendiri apa yang diketahuinya dan dapat menyelesaiakan masalah dalam pembelajaran matematika secara mandiri. Beliau menolak ide Piaget 
bahwa seseorang mengkonstruksi pengetahuannya secara mandiri, sementara beliau berpendapat bahwa seseorang mengkonstruksi pengetahuannya harus dibantu dan didukung oleh orang dewasa guna membantu memodelkan dan mengoreksi respon yang diberikan siswa.

Menurut Stuyf (2002), Vygotsky memandang bahwa scaffolding merupakan suatu teknik pembelajaran, dan mendefinisikannya sebagai "the role of teachers and others in supporting the learner's development and providing support structures to get to that next stage or level". yaitu menambahkan bahwa teknik scaffolding menjadi cara yang tepat untuk mencapai level potential developmental level dari level actual developmental level dalam Zone of Proximal Development (ZDP) dapat diartikan sebagai daerah antara apa yang dapat dilakukan siswa sendiri pada actual developmental level (tingkat perkembangan saat ini) dan apa yang dicapai siswa tersebut untuk potential developmental level (tingkat perkembangan potensial) bila dibantu oleh orang dewasa/ahli; dan scaffolding memainkan peranan yang penting untuk mencapai level perkembangan potensial tersebut.

Mamin (2008: 57) menyatakan bahwa tingkatan pengetahuan atau pengetahuan berjenjang disebut sebagai scaffolding. Scaffolding berarti memberikan kepada individu sejumlah besar bantuan selama bertahap-tahap awal pembelajaran dan kemudian mengurangi bantuan tersebut dan memberikan kesempatan kepada siswa tersebut untuk mengambil alih tanggung jawab yang semakin besar, segera setelah mampu mengerjakan sendiri. Bantuan yang

\section{METODE PENELITIAN}

Penelitian yang dilaksanakan adalah penelitian eksperimen posttest only control group designyaitu penelitian yang diberikan oleh pembelajar (guru) dapat berupa petunjuk, peringatan, dorongan, menguraikan masalah ke dalam bentuk lain yang memungkinkan siswa dapat mandiri.

Hutagoal (2013: 87) menyatakan bahwa representasi sebagai berpikir internal dan eksternal. Berpikir tentang ide matematika yang kemudian dikomunikasikan memerlukan representasi eksternal yang wujudnya antara lain verbal, gambar dan benda konkrit. Berpikir tentang ide matematika yang memungkinkan pikiran seseorang bekerja atas dasar ide tersebut merupakan representasi internal. Representasi internal tidak dapat diamati karena ada di dalam mental.

Representasi yang dimunculkan oleh siswa merupakan ungkapan-ungkapan dari gagasan-gagasan atau ide-ide matematika yang ditampilkan siswa dalam upayanya untuk mencari suatu solusi dari masalah yang sedang dihadapinya (Sabirin, 2014: 34). Adapun standar representasi yang ditetapkan National Council of Teacher of Mathematics NCTM (Kartini, 2009: 364) untuk program pembelajaran dari prataman kanak-kanak sampai kelas 12 adalah bahwa harus memungkinkan siswa untuk:

1. Membuat dan menggunakan representasi untuk mengatur, mencatat, dan mengkomunikasikan ide-ide matematika.

2. Memilih, menerapkan, dan menterjemahkan antar representasi matematika untuk memecahkan masalah

3. menggunakan representasi untuk memodelkan dan menginterpretasikan fenomena fisik, sosial, dan matematika.

menggunakan posttest pada pertemuan terakhir untuk membandingkan suatu kelompok (eksperimen) yang diberi 
perlakuan khusus dengan satu kelompok (kontrol) pembanding yang tidak menerima perlakuan khusus.

Populasi dalam penelitian ini adalah siswa kelas X SMK Negeri 05 Bombana yang terdaftar pada tahun ajaran
2017/2018 yang tersebar pada 3 jurusan yaitu kelas X Jurusan Multimedia, kelas X Jurusan Agribisnis Tanaman Pangan dan Holtikultural dan kelas X Jurusan Teknik Instalasi Tenaga Listrik. Secara singkat dapat dilihat pada Tabe1 berikut.

Tabel 1. Populasi Siswa Kelas X SMK Negeri 05 Bombana Semester Ganjil Matematika Menurut Ulangan Tengah SemesterTahun Ajaran 2017/2018

\begin{tabular}{lccccc}
\hline \multirow{2}{*}{ No } & \multirow{2}{*}{ Kelas } & \multicolumn{2}{c}{ Banyaknya siswa (orang) } & \multirow{2}{*}{ Jumlah } & \multirow{2}{*}{ Rata-Rata } \\
\cline { 3 - 4 } & & $\mathbf{P}$ & $\mathbf{L}$ & & \\
\hline 1. & X Multimedia & 14 & 10 & 24 & 56,76 \\
2. & XTITL & 12 & 12 & 24 & 52,53 \\
3. & X ATPH & 13 & 12 & 25 & 51,69 \\
\multicolumn{2}{r}{ Jumlah siswa } & & 73 & \\
\hline
\end{tabular}

Penentuan sampel dilakukan dengan menggunakan teknik purposive sampling yaitu yaitu dengan mengambil dua kelas yang mempunyai kemampuan representasi yang relatif sama dengan melihat rata-rata hasil ulangan tengah semester matematika siswa kelas X SMK Negeri 05 Bombana. Dari dua kelas tersebut, akan ditentukan kelas mana yang menjadi kelas eksperimen dan kelas kontrol secara random. Dua kelas yang dipilih yaitu kelas $\mathrm{X}$ Jurusan ATPH sebagai kelas eksperimen yang akan diajar dengan teknik Scaffolding dan Kelas X Jurusan TITL sebagai kelas kontrol yang akan diajar dengan pembelajaran konvensional.
Variabel yang digunakan dalam penelitian ini terdiri dari satu variabel bebas dan satu variabel terikat. Variabel bebas yaitu pembelajaran matematika dengan teknik scaffolding dan pembelajaran konvensional. Variabel terikat yaitu kemampuan representasi matematis antara siswa yang diajar dengan teknik scaffolding dan diajar dengan model pembelajaran konvensional.

Desain penelitian menggunakan posttest only control design. Adapun desain yang digunakan disajikan dalam Tabel 2 berikut.

Tabel 2. Desain Penelitian

\begin{tabular}{cccc}
\hline & Kelas & Perlakuan & Posttest \\
\hline $\mathrm{R}$ & $\mathrm{E}$ & $\mathrm{X}$ & $\mathrm{O}_{1}$ \\
$\mathrm{R}$ & $\mathrm{K}$ & - & $\mathrm{O}_{2}$ \\
\hline & & & (Sugiono, 2015)
\end{tabular}

Keterangan:

$\mathrm{E}=$ Kelas Eksperimen

$\mathrm{K}$ = Kelas Kontrol

$\mathrm{O}_{1}=$ Tes akhir di kelas eksperimen

$\mathrm{O}_{2}=$ Tes akhir di kelas kontrol

$\mathrm{X}=$ Pembelajaran teknik scaffolding pada kelas eksperimen

Instrumen adalah alat yang digunakan untuk mengumpulkan data penelitian. Instrumen dalam penelitian ini yaitu berupa tes kemampuan representasi matematis siswa antara yang diajar dengan teknik scaffolding dan yang diajar dengan pembelajaran konvensional. 
Sebelum instrumen penelitian digunakan, terlebih dahulu dilakukan uji validitas konstruk untuk menentukan berfungsi tidaknya suatu soal mengukur aspek kemampuan representasi matematis berdasarkan kriteria yang telah ditentukan, dalam hal ini adalah kriteria materi, konstruk, dan bahasa. Setelah dilakukan uji validitas konstruk diperoleh 5 butir soal valid dan reliabel yang kemudian digunakan untuk mengukur kemampuan representasi matematis siswa.

Validitas bertujuan untuk menentukan tingkat kehandalan alat ukur. Dalam menentukan validitas butir soal digunakan rumus korelasi Product Moment Pearson dengan mengkoerasikan antara skor yang didapat siswa pada suatu butir soal dengan skor total yang didapat. Digunakan rumus sebagai berikut:

$$
r_{x y}=\frac{N \sum X Y-\left(\sum X\right)\left(\sum Y\right)}{\sqrt{\left(N \cdot \Sigma X^{2}-\left(\sum X\right)^{2}\right) \cdot\left(N \cdot \Sigma Y^{2}-\left(\sum Y\right)^{2}\right)}}
$$

(Jihad, 2013: 179-180)
Keterangan:

$r_{x y}=$ Koefisien korelasi antara variabel $X$ dan variabel $\mathrm{Y}$

$\mathrm{N}=$ Banyaknya siswa

$X=$ Nilai hasil uji coba

$\mathrm{Y}=$ Nilai rata-rata harian

Kriteria pengujian sebagai berikut:

Jika $r_{x} \geq r_{\text {tabel }}$ dengan $\alpha=0,05$ maka item tersebut valid. Jika $r_{x}<r_{\text {tabel }}$ dengan $\alpha=0,05$ maka item tersebut tidak valid.

Reliabilitas tes dihitung dengan rumus alpha yaitu sebagai berikut

Keterangan:

$$
\left.r_{11=\left[\frac{n}{n-1}\right]}\right]\left[1-\frac{s_{i}{ }^{2}}{S_{t^{2}}}\right]
$$

$r_{11}=$ Koefisien reliabilitas

$s_{i^{2}}=$ Jumlah varians skor tiap item

$s_{t^{2}}=$ Varians skor total

$n \quad=$ Banyaknya butir soal yang ada

Interpretasi nilai $r_{11}$ untuk melihat reliabilitas soal mengacu pada kriteria berikut

Tabel 4. Kriteria Reliabilitas Butir Soal

\begin{tabular}{cl}
\hline Besar $\mathbf{r}$ & Interpretasi \\
\hline $0,00 \leq r_{11}<$ & Sangat rendah \\
0,20 & \\
$0,20 \leq r_{11}<0,40$ & Rendah \\
$0,40 \leq r_{11}<0,70$ & Sedang \\
$0,70 \leq r_{11}<0,90$ & Tinggi \\
$0,90 \leq r_{11}<1,00$ & Sangat tinggi \\
\hline
\end{tabular}

(Ruseffendi. 2013: 181)

Teknik analisis data dalam penelitian ini menggunakan dua teknik analisis, yaitu analisis deskriptif dan analisis inferensial. Analisis deskriptif merupakan analisis yang digunakan untuk mendeskripsikan data penelitian. Analisis inferensial digunakan untuk pengujian hipotesis penelitian, yang dilakukan dengan uji normalitas dan uji homogenitas sebagai uji prasyarat untuk melakukan uji hipotesis.

Pengujian hipotesis dengan uji-t, dilakukan untuk mengetahui apakah kemampuan repesentasi matematis siswa yang diajar dengan teknik scafflding lebih tinggi daripada kemampuan representasi matematis siswa yang diajar dengan menggunakan model pembelajaran konvensional.

\section{HASIL PENELITIAN}


Hasil penelitian ini meliputi analisis deskriptif dan analisis inferensial. Hasil analisis deskriptif nilai posttest kemampuan representasi matematis siswa pada kelas eksperimen disajikan dalam tabel 5 berikut.

Tabel 5. Deskriptif Kemampuan Representasi Matematis Siswa pada Kelas Eksperimen.

\begin{tabular}{lccc}
\hline \multirow{2}{*}{$\begin{array}{c}\text { Statistik } \\
\text { Deskriptif }\end{array}$} & \multicolumn{3}{c}{ Kelas Eksperimen } \\
\cline { 2 - 4 } \multicolumn{1}{c}{$\begin{array}{c}\text { Representasi } \\
\text { Gambar }\end{array}$} & $\begin{array}{c}\text { Representa } \\
\text { si Simbol }\end{array}$ & $\begin{array}{c}\text { Representasi } \\
\text { Verbal }\end{array}$ \\
\hline Rata-rata & 67,56 & 78,92 & 74,80 \\
$\mathrm{~N}$ & 25 & 25 & 25 \\
Standar error & 2,945 & 2,124 & 2,653 \\
Standar & 14,725 & 10,618 & 13,266 \\
Deviation & & & \\
Modus & 62 & 81 & 75 \\
Variance & 216,840 & 112,743 & 176,000 \\
\hline
\end{tabular}

Hasil analisis deskriptif kemampuan representasi matematis siswa pada kelas eksperimen sebagaimana disajikan pada tabel 5 diperoleh nilai rata-rata pada setiap indikator kemampuan representasi matematis siswa berbeda-beda, diantaranya nilai rata-rata pada kemampuan representasi gambar yaitu 67,56, simbol 78,92 verbal yaitu 74,80, median atau Berdasarkan nilai rata-rata kemampuan representasi matematis siswa pada kelas eksperimen dapat disimpulkan bahwa kemampuan representasi matematis siswa yang memperoleh nilai rata-rata terendah yaitu terletak pada kemampuan representasi gambar.

Hasil analisis deskriptif nilai posttest kemampuan representasi matematis siswa pada kelas kontrol disajikan dalam tabel 6 berikut.

Tabel 6. Deskriptif Kemampuan Representasi Matematis Siswa pada Kelas Kontrol

\begin{tabular}{llll}
\hline \multicolumn{1}{c}{ Statistik } & \multicolumn{3}{c}{ Kelas Kontrol } \\
\cline { 2 - 4 } \multicolumn{1}{c}{ Deskriptif } & \multicolumn{1}{c}{$\begin{array}{c}\text { Representasi } \\
\text { Gambar }\end{array}$} & $\begin{array}{c}\text { Representasi } \\
\text { Simbol }\end{array}$ & $\begin{array}{c}\text { Representasi } \\
\text { Verbal }\end{array}$ \\
\hline Rata-rata & 53,96 & 66,79 & 62,92 \\
$\mathrm{~N}$ & 24 & 24 & 24 \\
Standar error & 2,860 & 2,036 & 1,949 \\
Standar Deviation & 14,011 & 9,974 & 9,546 \\
Modus & 56 & 62 & 65 \\
Variance & 196,303 & 99,476 & 91,123 \\
\hline
\end{tabular}

Hasil analisis deskriptif kemampuan representasi matematis siswa pada kelas kontrol sebagaimana disajikan pada tabel 6 diperoleh nilai rata-rata pada setiap indikator kemampuan representasi matematis siswa berbeda-beda, diantaranya nilai rata-rata pada kemampuan representasi gambar yaitu 53,96, simbol 66,79 dan verbal yaitu 62,92. Berdasarkan nilai rata-rata kemampuan representasi matematis siswa pada kelas kontrol dapat disimpulkan bahwa kemampuan representasi matematis siswa yang memperoleh nilai rata-rata terendah yaitu terletak pada kemampuan representasi gambar.

Berdasarkan tabel 5 dan tabel 6 diketahui hasil analisis deskriptif kemampuan representasi matematis siswa menunjukkan bahwa kemampuan 
representasi matematis siswa pada kelas eksperimen yang diajar dengan teknik scaffolding lebih tinggi dibandingkan dengan kemampuan representasi matematis siswa yang diajar dengan pembelajaran konvensional, hal itu dapat dilihat berdasarkan nilai rata-rata pada setiap indikator kemampuan representasi matematis siswa.
Uji normalitas digunakan untuk mengetahui apakah data kemampuan representasi matematis siswa kedua kelas berdistribusi normal atau tidak. Untuk menguji apakah data berdistribusi normal atau tidak digunakan statistik uji normalitas Liliefors dengan menggunkan bantuan aplikasi IBM SPSS Statistics. Hasil perhitungan dapat dilihat pada Tabel 7.

Tabel 7. Hasil Analisis Uji Normalitas Data Posttest

\begin{tabular}{|ccc}
\hline & Eksperimen & Kontrol \\
\hline $\begin{array}{c}\text { Asymp. Sig. } \\
2 \text { (2-tailed) }\end{array}$ & 0,407 & 0,516 \\
\hline
\end{tabular}

Pengambilan keputusan untuk normalitas data adalah sebagai berikut:

$\mathrm{H}_{0}$ : Data berdistribusi normal

$\mathrm{H}_{1}$ : Data tidak berdistribusi normal,

Dengan kriteria pengujian :

$\mathrm{H}_{0}$ diterima, jika nilai Asymp.Sig. $>\alpha$ $(0,05)$

Berdasarkan hasil analisis perhitungan uji normalitas diperoleh untuk kelas eksperimen nilai Asymp. Sig(2tailed) $=0,407>0.05=\alpha$ maka $\mathrm{H} 0$ diterima. Hal ini berarti bahwa data kemampuan representasi matematis siswa pada kelas eksperimen berdistribusi normal. Sedangkan untuk kelas kontrol diperoleh nilai Asympt. Sig(2-tailed)= $0,516>0.05=\alpha$ maka $\mathrm{H} 0$ diterima. Hal ini berarti bahwa data kemampuan representasi matematis siswa pada kelas kontrol berdistribusi normal.

Berdasarkan hasil uji homogenitas varians data dari kedua kelompok sampel dengan bantuan IBM SPSS Statistics. Hasil perhitungan dapat dilihat pada Tabel 8 .

Tabel 8. Hasil Analisis Uji Homogenitas Varians Data Posttest

\begin{tabular}{llll}
\hline Levene Statistic & df1 & df2 & Sig \\
\hline 0.743 & 1 & 47 & 0.393 \\
\hline
\end{tabular}

Berdasarkan hasil analisis uji homogenitas varians diperoleh nilai $\mathrm{Sig}=$ 0,393. Karena nilai Sig $=0,393>0.05=\alpha$ maka H0 diterima. Hal ini berarti bahwa data yang diperoleh memiliki varians yang homogen.
Pengujian hipotesis menggunakan uji-t data sampel saling bebas (Independent Sample t-test) dilakukan dengan rumus uji-t menggunakan IBM SPSS Statistics. Adapun hasil analisis uji hipotesis dapat dilihat pada tabel 9 berikut

Tabel 9. Hasil Uji Hipotesis

\begin{tabular}{llclllll}
\hline & & \multicolumn{4}{c}{ Levene's Test For Equality Of Variances } \\
& & & f & Sig & t & df & Sig.(2-tailed) \\
\hline $\begin{array}{l}\text { Nilai } \\
\text { assumed }\end{array}$ & Equal & variances & 0,743 & 0,393 & 4,455 & 47 & 0,000 \\
$\begin{array}{l}\text { Equal } \\
\text { assumed }\end{array}$ & Variances & & & & & & \\
\hline
\end{tabular}


Berdasarkan hasil analisis uji-t diperoleh thitumg $=4,455$ atau nilai $\frac{\text { sig }(2-\text { tailed })}{2}=\frac{0,000}{2}=0.000<0,05$, maka H0 ditolak sehingga terdapat

\section{PEMBAHASAN}

Pembelajaran dalam penelitian ini yaitu pembelajaran dengan menggunakan teknik scaffolding. Teknik scaffolding adalah teknik pemberian bantuan oleh guru kepada siswa pada proses pembelajaran disaat yang tepat, yaitu ketika siswa kesulitan dalam menyelesaikan permasalahannya. Guru menghentikan bantuan tersebut dengan memberikan kesempatan kepada siswa untuk mengambil alih tanggung jawab dalam menyelesaikan permasalahan yang diberikan oleh guru dan kemudian siswa mampu untuk menyelesaikan permasalahan sehingga dapat mencapai tujuannnya dalam proses pembelajaran.

Adapun materi yang dibahas pada pertemuan pertama yaitu perbandingan trigonometri pada segitiga siku-siku. Tujuan pembelajaran yang hendak dicapai yaitu siswa dapat menentukan nilai perbandingan trigonometri (sinus, kosinus, tangen, kotangen, sekan dan kosekan) pada segitiga siku-siku. Penelitian ini menggunakan LKS dengan tujuan untuk menemukan konsep matematika, dimana masalah-masalah yang diberikan oleh guru dalam pembelajaran yang disajikan secara tertulis atau dalam bentuk LKS. Adapun LKS yang digunakan didesain agar siswa mampu menemukan konsep matematika dari materi yang dipelajari berdasarkan pengalamannya sendiri. Namun dalam pelaksanaan pembelajaran dengan LKS ini ada beberapa siswa yang mampu menyelesaikan masalah dalam LKS sampai penemuan konsep dan ada juga siswa yang belum mampu memberikan kesimpulan dari masalah yang diselesaikan yang disebabkan terbatasnya waktu pembelajaran yang ditetapkan apalagi konsep yang dibangun dalam materi trigonometri. perbedaan kemampuan representasi matematis siswa yang diajar dengan teknik scaffolding dan yang diajar dengan pembelajaran konvensional

Guru kemudian menyampaikan materi yang hendak diajarkan terlebih dahulu kepada siswa. Langkah awal yang dilakukan guru yaitu menjelaskan pengertian trigonometri. Selanjutnya, guru menyampaikan kepada siswa tentang pengertian segitiga dan segitiga siku-siku. Setelah mengetahui ketiga pengertian tersebut, langkah yang dilakukan guru yaitu menjelaskan hubungan perbandingan trigonometri dengan terlebih dahulu menjelaskan bahwa di dalam trigonometri terdapat istilah sinus, kosinus, tangen, kotangen, sekan dan kosekan. Siswa mendengarkan dan memperhatikan penjelasan yang diberikan guru.

Guru membagikan LKS-01 kepada siswa untuk melatih siswa apakah siswa paham dengan penjelasan yang diberikan guru, dari LKS yang diberikan tersebut siswa mencari cara atau langkah penyelesaian yang diberikam secara individu dan guru membiarkan siswa untuk menyelesaikan permasalahan yang terdapat pada LKS yang diberikan, dari permasalahan yang terdapat pada LKS tersebut akan membantu siswa untuk berpikir lebih dalam untuk merepresentasikan jawaban mereka mengenai perbandingan trigonometri pada segitiga siku-siku. Selama dalam proses menyelesaikan soal yang terdapat pada LKS dan siswa memberikan kode sudah dalam keadaan kesulitan dalam menyelesaikan soal yang diberikan mengenai perbandingan trigonometri pada segitiga siku-siku barulah guru memberikan bantuannya berupa bimbingan secara bertahap. Bantuan tersebut dapat berupa penjelasan, petunjuk, dorongan, peringatan. Memberikan penjelasan pada siswa 
sehingga siswa dapat menyelesaikan masalah yang diberikan dalam bentuk LKS ke dalam langkah-langkah representasi matematis atau memberikan contoh lain atau hal-hal yang dapat memancing cara berpikir siswa ke arah kemandirian dalam menyelesaikan soal. Apabila siswa mengerti dengan penjelasan yang diberikan maka guru menghentikan bantuanya dan membiarkan siswa untuk menyelesaikan soalnya secara mandiri sampai tahap akhir.

Selanjutnya, apabila masalah yang diberikan pada LKS dapat diselesaikan sesuai dengan langkah-langkah representasi matematis, maka siswa diberikan kesempatan untuk membuat kesimpulan mengenai langkah-langkah penyelesaian perbandingan trigonometri. Setelah siswa dapat membuat kesimpulan maka guru meminta kepada siswa untuk mmerepresentasikan hasil penyelesaian di depan kelas dan menuliskannya di papan tulis.

Proses pembelajaran pada pertemuan kedua sampai pertemuan keempat berjalan dengan baik dan lancar. Pada proses pembelajaran pertemuan kedua sampai pertemuan keempat pemberian bantuan dengan teknik scaffolding apabila siswa diberikan masalah dalam bentuk LKS, siswa merasa senang dan antusias karena merasa bahwa masalah yang diberikan pada LKS tersebut harus segera diselesaikan. Namun dalam proses menyelesaikan masalah proses pemberian bantuan bukan lagi guru yang datang menghampiri siswa tetapi siswa langsung yang datang menghampiri guru. Hal itu terjadi dikarenakan siswa merasa sangat termotivasi dan senang karena pembelajaran dengan pemberian bantuan ini tidak pernah mereka dapatkan selama proses pembelajaran berlangsung.

Proses pembelajaran Pada kelas kontrol yaitu kelas X Jurusan Teknik Instalasi Tenaga Listrik (TITL). Proses pembelajaran berlangsung sesuai dengan langkah-langkah pembelajaran konvensioanal yaitu pada awal pembelajaran guru memberikan informasi tujuan pembelajaran kemudian guru menyampaikan materi pelajaran yang hendak akan diajarkan. Selanjutnya, guru melaksanakan bimbingan kemudian guru memberikan kesempatan kepada siswa untuk berlatih setelah itu guru menilai kinerja siswa dan memberikan umpan balik dan diakhir pelajaran guru memberikan latihan mandiri.

Penerapan langkah-langkah dengan pembelajaran konvensional pada kelas $\mathrm{X}$ Jurusan TITLpada awal pertemuan setelah guru memberikan apersepsi dengan mereview materi terlebih dahulu yang akan diajarkan yaitu perbandingan trigonometri pada segitiga siku-siku. Selanjutnya, guru memberikan penjelasan kepada siswa mengenai tujuan pembelajaran yang akan dicapai yaitu siswa dapat menentukan nilai perbandingan trigonometri (sinus, kosinus, tangen, kotangen, sekan, dan kosekan pada suatu sudut) pada segitiga siku-siku. Kemudian guru memberikan motivasi kepada siswa apabila materi dapat dikuasai dengan baik maka dapat membantu siswa dalam memahami materi berikutnya dan mempermudah menyelesaikan masalah dan soal- soal yang berkaitan dengan materi perbandingan trigonometri pada segitiga siku-siku.

Siswa mendengarkan dan memperhatikan penjelasan guru mengenai materi yang diajarkan. Kemudian siswa diberi kesempatan untuk mencatat. Setelah selesai menjelaskan materi guru memberikan contoh soal kepada siswa secara mandiri hal itu dilakukan untuk menilai tingkat kepahaman siswa mengenai materi yang diajarkan. Selanjutnya, siswa memperhatikan contoh soal yang diberikan kepada guru dan mengerjakannya secara mandiri. Apabila ada masalah yang belum dimengerti maka guru memberikan kesempatan kepada 
siswa untuk mengajukan pertanyaan sesuai dengan maslah yang dihadapinya. Guru kemudian menilai kinerja siswa dan memberikan umpan balik. Guru memberikan review terhadap hal-hal yang dilakukan siswa, memberikan umpan balik terhadap jawaban yang benar dan mengoreksi jawaban yang salah. Guru mengarahkan kepada siswa untuk membuat rangkuman dan memebrikan penegasan terhadap materi yang telah diperlajari. Pada akhir pelajaran guru memberikan tugas kepada siswa untuk dikerjakan secara mandiri. Hal itu dilakukan untuk mengecek kemampuan representasi siswa terhadap materi yang telah diajarkan.

Proses pembelajaran pada pertemuan kedua dan keempat tidak jauh berbeda dengan proses pembelajaran pada pertemuan pertama. Proses pembelajaran berlangsung sesuai pembelajaraan pada kelas X Jurusan TITL berlangsung sesuai dengan langkah-langkah pembelajaran konvensional dari pertemuan pertama sampai dengan pertemuan terakhir.

Berdasarkan hal tersebut di atas dapat disimpulkan bahwa pembelajaran dengan menggunakan teknik scaffolding yang diterapkan dalam pembelajaran matematika di sekolah mempunyai pengaruh terhadap kemampuan representasi matematis siswa. Hal ini terjadi karena pembelajaran dengan teknik scaffolding merupakan teknik pemberian bantuan dimana siswa dan guru saling betukar perdapat untuk menyelesaikan masalah dan siswa bertanggung jawab secara mandiri untuk menyelesaikan masalah yang diberikan.

Penelitian ini meliputi data kemampuan representasi matematis siswa yang diajar dengan teknik scaffolding dan yang diajar dengan pembelajaran konvensional. Data hasil analisis deskriptif bahwa nilai rata- rata kemampuan representasi siswa pada kelas X Agribisnis ATPH memiliki nilai rata rata kemampuan representasi gambar yaitu 67,56, kemampuan representasi simbol memiliki nilai rat-rata 78,92 dan representasi verbal memiliki rata-rata 74,80 sedangkan pada kelas X Jurusan TITL memiliki nilai ratarata kemampuan representasi gambar yaitu 53,96, kemampuan representasi simbol memilik nilai rata-rata 66,79 dan kemampuan representasi verbal memiliki nilai rata-rata 62,92.

Berdasarkan hasil analisis uji-t diperoleh thitumg $=4,455$ atau nilai $=$ $\frac{\text { nilai (sig 2-tailed) }}{2} \quad \frac{0,000}{2}=0.000<0,05$, maka H0 ditolak. Dengan ditolaknya H0 maka dapat dikatakan bahwa terdapat perbedaan kemampuan representasi matematis siswa yang diajar dengan teknik scaffolding dan yang diajar dengan pembelajaran konvensional sehingga dapat disimpulkan bahwa terdapat perbedaan yang signifikan kemampuan representasi matematis siswa yang diajar dengan teknik scaffolding dan yang dengan pembelajaran konvensional.

Penelitian ini dikatakan memiliki perbedaan kemampuan representasi matematis siswa yang diajar dengan teknik scaffolding lebih baik daripada kemampuan representasi matematis siswa diajar dengan pembelajaran konvensional. Hal tersehut diakibatkan katena telah memenuhi empat fase dalam pembelajaran dengan teknik scaffolding: (1) pemodelan, dengan penjelasan secara verbal, (2) peniruan terhadap pemodelan oleh guru, (3) masa ketika guru mulai menghilanhkan bantuannya, dan (4) siswa telah mencapai level penguasaan.

Jadi pada penelitian ini terdapat perbedaan kemampuan representasi matematis siswa yang diajar dengan teknik scaffolding dan yang diajar dengan pembelajaran konvensional atau dengan kata lain pembelajaran dengan teknik scaffolding lebih tinggi daripada penerapan dengan pembelajaran konvensional terhadap kemampuan representasi matematis siswa. 


\section{KESIMPULAN DAN SARAN}

Berdasarkan hasil penelitian dan pembahasan, maka dapat ditarik beberapa kesimpulan berikut:

1. Kemampuan representasi matematis siswa kelas X Jurusan ATPH yang diajar dengan teknik scaffolding pada materi trigonometri memiliki nilai rata-rata kemampuan representasi gambar 67,56 dengan nilai minimum sebesar 43 dan nilai maksimum sebesar 93, rata-rata kemampuan representasi simbol 78,92 dengan nilai minimum sebesar 56 dan nilai maksimum sebesar 100 dan rata-rata kemampuan representasi verbal 74,80 dengan nilai minimum sebesar 55 dan nilai maksimum sebesar 100

2. Kemampuan representasi matematis siswa kelas $\mathrm{X}$ Jurusan TITL yang diajar dengan pembelajaran konvensional pada materi trigonometri memiliki nilai rata-rata kemampuan representasi gambar 53,96 dengan nilai minimum sebesar 31 dan nilai maksimum sebesar 81, rata-rata kemampuan representasi simbol 66,79 dengan nilai minimum sebesar 56 dan nilai maksimum sebesar 87 dan ratarata kemampuan representasi verbal 62,92 dengan nilai minimum sebesar 40 dan nilai maksimum sebesar 80 .

3. Kemampuan representasi matematis siswa yang diajar dengan teknik scaffolding lebih tinggi dari pada kemampuan representasi matematis

\section{DAFTAR PUSTAKA}

Abdurrahman, M. 2003. Pendidikan Bagi Anak Berkesulitan Belajar. Jakarta: Rineka Cipta.

Effendi, A. L. 2013. Pembelajaran Matematika dengan Metode Penemuan Terbimbing untuk Meningkatkan Kemampuan Representasi Dan Pemecahan Masalah Matematis siswa SMP. siswa yang diajar dengan pembelajaran konvensional.

Berdasarkan kesimpulan yang diperoleh dalam penelitian ini, maka peneliti memberikan saran-saran sebagai berikut:

1. Kepada pada guru yang mengajarkan mata pelajaran matematika hendaknya menerapkan pembelajaran dengan teknik scaffolding karena dengan teknik scaffolding siswa dapat berpikir lebih dalam untuk menyelesaikan permasalahan yang diberikan oleh guru. Sehingga sisswa dapat menyelesaikan pemasaahan terseut dan dapat menarik kesimpulan dari permasalahan yang didapainya.

2. Kemampuan representasi matematis siswa seharusnya menjadi perhatian khusus bagi guru mata pelajaran matematika, karena dengan berkembangnya kemampuan representasi matematis siswa maka siswa akan lebih mudah untuk menyelesaikan pemasalahna matematika dan dapat mengembangkan kemampuan representasi yang dimilikinya.

Bagi peneliti yang hendak akan melakukan penelitian dengan menggunkan teknik scaffolding sebaiknya dapat menggunkan teknik ini sebaik mungkin karena dengan teknik scaffolding siswa merasa terbantu dan termotivasi untuk belajara matematika

Hamalik, O. 2002. Psikologi Belajar Mengajar. Bandung: Sinar Baru

2008. Proses Belajar Mengajar. Jakarta: Bumi Aksara.

Hudoyo, H. 2003. Pengembangan Kurikulum dan Pembelajaran Matematika, Malang: Universitas Negeri Malang. 
Hutagoal, K. 2013. Pembelajaran Kontekstual Untuk Meningkatkan Kemampuan Representasi Matematis Siswa Sekolah Menengah Pertama. Jurnal Ilmiah Program Studi Matematika STKIP Siliwangi Bandung, 2(1): 85-99.

Jihad, H. 2013. Evaluasi Pembelajaran. Yogyakarta: Multi Pressindo.

Kartini. 2009. Peranan Representasi Dalam Pembelajaran Matematika, (Dosen Pendidikan Matematika FKIP UNRI). 3(2): 361-372.

Lie, A. 2005. Cooperative Learning. Jakarta: Grasindo.

Mamin, R. 2008. Penerapan metode Pembelajaran Scaffolding Pada Pokok Bahasan Sistem Periodik Unsur. Jurnal Chemica, 10 (2) : 5560.

Magvira. 2014. Perbedaan Hasil Belajar Matematika Ditinjau Dari Model Pembelajaran Kooperatif dan Kemampuan IPA. Skripsi FKIP UHO, Kendari.

Nofiansyah , W., Sujadi, I., dan Kusmayadi, A. T. 2015. Analisis Proses Scaffolding Pada Pembelajaran Matematika di Kelas VIII SMP Negeri 4 Karanganyar Tahun Pelajaran 2013/2014. Jurnal Elektronik Pembelajaran Matematika, 3(9): 947-958

Sabirin, M. 2014. Representasi Dalam Pembelajaran Matematika. JPM IAIN Antasari, 01 (2): 33-44.

Sudjana, Nana. 2005. Metode Statistik. Tarsito. Bandung

Sabirin Muhamad. 2014. Representasi dalam pembelajaran matematika, 01(2): 33-44

Syah Muhibbin. 2015. Psikolgi Belajar, Jakarta : PT RajaGrafindo Persada.
2000. Psikologi Pendidikan Dengan Pendekataan Baru. rev. ed. Bandung: Remaja Rosdakarya

Sudijono, Anas. 2015. Pengantar Statistik Pendidikan. Jakarta: PT Rajagrafindo Persada.

Supriadi, D. M. P. 2017. Statistik Penelitian Pendidikan. Depok: PT Rajagrafindo Persada. 